\title{
Content of Building Intercultural Competence in Future Specialists of Combat and Operational Support
}

\author{
Liubas Anzhelika \\ ORCID http://orcid.org/0000-0001-6068-6065 \\ Postgraduate Student at the Department of Pedagogical Education \\ Ivan Franko National University of Lviv (Ukraine, Lviv)
}

\begin{abstract}
The article deals with a crucial research issue of acquiring intercultural competence by future specialists of combat and operational support. Following the recent researches intercultural competence of future specialists of combat and operational support is interpreted as an ability to cooperate with professionals - representatives of other cultures with regard for their values, norms, traditions and images and also choose the expedient ways of verbal and nonverbal communication with the aim to solve professional problems. The components of intercultural competence of future specialists of combat and operational support include knowledge (language, speech, multicultural knowledge, knowledge of verbal and nonverbal communicative rules of behavior, cognitive knowledge), skills and abilities (speech skills and abilities, cognitive skills, an ability to control own actions in communication). While studying disciplines "Foreign language", "Foreign language for Specific Purposes" students acquire basic elements of foreign language system, develop and improve speech knowledge, skills and abilities. Introduction into third year students' syllabus the discipline "Intercultural Communication in Professional Cooperation" and organization of learning and field training envisages implementation of intercultural competence while performing professional duties and functions.

Key word: intercultural competence, future specialists of combat and operational support, discipline, syllabus.
\end{abstract}

Актуальність дослідження. У сучасних умовах глобалізації та світової інтеграції, а поруч із тим взаємодопомоги і взаємопідтримки держав у процесі вирішення існуючих військових конфліктів, особливого значення набуває володіння військовослужбовцями, зокрема фахівцями бойового та оперативного забезпечення, міжкультурною компетентністю з метою забезпечення здатності повноцінно виконувати професійні обов'язки та функції у процесі міжнародних спільних навчань та миротворчих операцій.

Проблемі формування міжкультурної компетентності присвячено розвідки таких науковців як М. Байрам, М. Беннет, Л. Гребенюк, О. Зеліковська, З. Корнєва, Л. Петько, А. Садохін та ін., особливості формування і розвитку міжкультурної компетентності майбутніх військовослужбовців досліджували О. Антонова, О. Дубасенюк, Л. Маслак та ін. Здійснений аналіз науково-педагогічної літератури доводить, що на сьогоднішній день не 
існує комплексного дослідження, присвяченого змісту формування міжкультурної компетентності майбутніх фахівців бойового та оперативного забезпечення.

Мета статті - обгрунтувати і сконструювати зміст формування міжкультурної компетентності майбутніх фахівців бойового та оперативного забезпечення.Виклад основного матеріалу. Задля обгрунтування й конструювання змісту формування міжкультурної компетентності майбутніх фахівців бойового та оперативного забезпечення звернемось до сутності поняття «міжкультурна компетентність майбутніх фахівців бойового та оперативного забезпечення» та його структури.

3 урахуванням результатів здійснених досліджень розглядаємо міжкультурну компетентність як здатність особи взаємодіяти з представниками інших культур на основі врахування їхніх цінностей, норм, традицій, уявлень, а також обирати комунікативно доцільні способи невербальної і вербальної поведінки [7, с. 51]. Відповідно, міжкультурну компетентність майбутніх фахівців бойового та оперативного забезпечення трактуємо як здатність иүи фахівців взаємодіяти з професіоналами представниками інших культур на основі врахування їхніх иүінностей, норм, традицій, уявлень, а також обирати комунікативно доцільні способи невербальної $і$ вербальної поведінки з метою вирішення завдань професійного характеру.

До компонентів міжкультурної компетентності майбутніх фахівців бойового оперативного забезпечення відносимо наступні знання, вміння і навички: 1) мовні знання (фонетичні, лексичні, граматичні, орфографічні), вміння і навички; 2) мовленнєві знання, навички та вміння (вести діалог 3 представниками інших культур, аналізувати мовленнєву ситуацію, дотримання норм етикету); 3) полікультурні знання; 4) знання вербальних та невербальних комунікативних правил поведінки; 5) когнітивні знання $i$ навички; 6) здатність контролювати власні дії під час спілкування [3; 4, с. 50-51; 6; 12; $14]$.

На сьогоднішній день зміст професійної підготовки майбутніх фахівців бойового та оперативного забезпечення у закладах вищої освіти України формується на основі: вимог та положень освітньо-кваліфікаційних характеристик, освітньо-професійних програм підготовки військових фахівців, сучасної політики щодо застосування підрозділів і частин у збройних конфліктах, особливостей ведення бойових дій підрозділами збройних сил України у складі сил АТО.Формування і розвиток у майбутніх 
фахівців бойового та оперативного забезпечення знань, умінь і навичок - компонентів міжкультурної компетентності здійснюється у процесі вивчення ними нормативних навчальних дисциплін «Іноземна мова», «Іноземна мова за професійним спрямуванням» та розробленого і запропонованого вибіркового спецкурсу «Міжкультурна комунікація у професійній співпраці». Зміст перелічених дисциплін формується на засадах міжпредметних зв'язків з іншими дисциплінами гуманітарної та соціально-економічної підготовки [5; 6], природничо-наукової підготовки, базової підготовки, загальнопрофесійної підготовки, військово-професійної підготовки та військово-спеціальної підготовки майбутніх фахівців бойового та оперативного забезпечення. Так, аналіз навчальних планів підготовки майбутніх бакалаврів бойового та оперативного забезпечення в українських закладах вищої освіти дозволяє стверджувати, що конструювання змісту навчальних дисциплін «Іноземна мова», «Іноземна мова за професійним спрямуванням» та «Міжкультурна комунікація у професійній співпраці» 3 метою формування у цих фахівців міжкультурної компетентності має здійснюватись на основі міжпредметної координації 3 певними дисциплінами. Перелік навчальних дисциплін відповідних блоків дисциплін, змістове наповнення яких ураховується у процесі конструювання змісту навчальних дисциплін «Іноземна мова», «Іноземна мова за професійним спрямуванням» та «Міжкультурна комунікація у професійній співпраці», представлено у таблиці 1.

Таблиияя 1

Навчальні дисципліни у змісті курсів «Іноземна мова», «Іноземна мова за професійним спрямуванням», «Міжкультурна комунікація у професійній співпраці»

\begin{tabular}{|l|l|}
\hline \multicolumn{1}{|c|}{ Навчальна дисципліна } & \multicolumn{1}{|c|}{ Блок дисциплін } \\
\hline $\begin{array}{l}\text { Основи військового управління (штабні } \\
\text { процедури НАТО) }\end{array}$ & $\begin{array}{l}\text { Блок дисциплін загально професійної } \\
\text { підготовки }\end{array}$ \\
\hline $\begin{array}{l}\text { Правознавство (міжнародне гуманітарне } \\
\text { право) }\end{array}$ & $\begin{array}{l}\text { Блок дисциплін загально професійної } \\
\text { підготовки }\end{array}$ \\
\hline Автомобільна техніка & $\begin{array}{l}\text { Блок дисциплін професійної і } \\
\text { практичної підготовки }\end{array}$ \\
\hline Бойова система виживання воїна & $\begin{array}{l}\text { Блок дисциплін військово-професійної } \\
\text { підготовки }\end{array}$ \\
\hline
\end{tabular}




\begin{tabular}{|l|l|}
\hline Стрілецька зброя та вогнева підготовка & $\begin{array}{l}\text { Блок дисциплін професійної i } \\
\text { практичної підготовки }\end{array}$ \\
\hline Озброєння і стрільба & $\begin{array}{l}\text { Блок дисциплін військово-спеціальної } \\
\text { підготовки }\end{array}$ \\
\hline Розвідувальна підготовка & $\begin{array}{l}\text { Блок дисциплін військово-спеціальної } \\
\text { підготовки }\end{array}$ \\
\hline Основи застосування артилерії & $\begin{array}{l}\text { Блок дисциплін військово-спеціальної } \\
\text { підготовки }\end{array}$ \\
\hline Будова бронетанкової техніки & $\begin{array}{l}\text { Блок дисциплін військово-спеціальної } \\
\text { підготовки }\end{array}$ \\
\hline Експлуатація бронетанкової техніки & $\begin{array}{l}\text { Блок дисциплін військово-спеціальної } \\
\text { підготовки }\end{array}$ \\
\hline
\end{tabular}

3 огляду на особливості майбутньої професійної діяльності й сучасні умови професійної підготовки майбутніх фахівців бойового та оперативного забезпечення, у процесі вивчення навчальних дисциплін «Іноземна мова», «Іноземна мова за професійним спрямуванням» та «Міжкультурна комунікація у професійній співпраці», студенти повинні оволодіти іншомовним лексичним матеріалом щодо основ військового управління у рамках штабних процедур НАТО; міжнародного гуманітарного права; автомобільної техніки, яка застосовується у військовій справі; бронетанкової техніки та іï експлуатації; озброєння і стрільби, зокрема стрілецької зброї та вогневої підготовки; бойової системи виживання воїна; основ застосування артилерії, розвідувальної підготовки. При цьому особливу увагу слід приділяти особливостям міжкультурної взаємодії й міжкультурної комунікації у процесі вирішення професійних завдань.

Програми вивчення нормативних навчальних дисциплін «Іноземна мова» та «Іноземна мова за професійним спрямуванням» укладаються відповідно до освітньопрофесійної програми підготовки освітньо-кваліфікаційного рівня «бакалавр» підготовки військових фахівців у закладах вищої освіти України.

Через що, предметом вивчення навчальних дисциплін «Іноземна мова» та «Іноземна мова за професійним спрямуванням» є оволодіння основними елементами системи іноземної мови, а також формування, розвиток і вдосконалення мовних i мовленнєвих знань, умінь та навичок, які забезпечують сприйняття інформації, а також спілкування іноземною мовою у професійній сфері в усній та письмовій формах й 
спрямовані на реалізацію міжкультурної комунікації у процесі виконання професійних обов'язків і функцій.

Метою вивчення навчальних дисииплін «Іноземна мова» та «Іноземна мова за професійним спрямуванням» $\epsilon$ підготовка курсантів до майбутнього ефективного спілкування іноземною мовою у їхньому професійному оточенні та формування необхідних офічерських якостей, поглядів на характер сучасного бою, на роль $i$ призначення підрозділів (частин) родів військ, видів збройних сил.

Програми навчальних дисциплін визначають перелік компетентностей, які мають бути сформовані у курсантів у процесі вивчення цих дисциплін. До цього переліку належать: 1) комунікативна компетентність як здатність установлювати та підтримувати контакти з особами; сукупність знань, умінь і навичок, що забезпечують ефективне спілкування [10; 17]; 2) міжкультурна компетентність як здатність успішно будувати міжкультурну взаємодію та вести міжкультурну комунікацію з представниками інших культур; 3) інформаційна компетентність як здатність здобувати, осмислювати, опрацьовувати та використовувати інформацію з різноманітних джерел [2]; 5) соціальна компетентність як здатність виявляти відкритість до світу та відповідальність за навколишнє середовище, вміння працювати у співпраці та приймати діяльність демократичних інститутів суспільства [2]; 6) етична компетентність як здатність толерувати традиції, принципи життя і професійної діяльності, вчинки і якості оточуючих [9].

Тому, в результаті вивчення згаданих дисципліни у курсантів повинні бути сформовані: 1) знання, щзо є компонентами міжкультурної компетентності, а саме: лексичні знання (близько 2000 лексичних одиниць загальновживаної, соціальнопобутової, загальновійськової та вузькоспеціалізованої лексики; словотворчі морфеми $i$ моделі, характерні для сучасної іноземної мови); граматичні знання (граматичні явища в межах відібраного за тематичним принципом навчального матеріалу); орфографічні; мовленнєві знання (ведення бесіди, аудіювання, роботи з автентичною літературою професійного та соціально-побутового характеру; знання вербальних та невербальних комунікативних правил поведінки); полікультурні знання;2) навички і вміння: мовленнєві (сприйняття на слух інформації, повідомлення, що подається в нормальному темпі і має відношення до професійної, загально-побутової та соціально-культурної тематики; 
ведення діалогу з представниками інших культур, викладу думок у зрозумілій для співрозмовника формі; ведення бесіди в межах вивченої тематики і повідомлення іноземною мовою; читання тексту професійного та соціально-побутового характеру 3 різними завданнями: для загального ознайомлення з інформацією, для повного і точного розуміння інформації (з використанням словника), для отримання загального уявлення про зміст тексту, для виокремлення у тексті потрібної інформації; аналізу мовленнєвої ситуації; подолання комунікативних бар'єрів та страху; дотримання норм етикету.

3 метою формування високого рівня міжкультурної компетентності майбутніх фахівців бойового та оперативного забезпечення вважаємо доцільним ввести до навчальних планів підготовки бакалаврів третього року навчання дисципліну «Міжкультурна комунікація у професійній співпраці» та організувати навчальні й виробничі польові практики, а також військові стажування мовою глобального спілкування - англійською.

Володіння студентами англійською мовою по завершенні вивчення ними дисциплін «Іноземна мова», «Іноземна мова за професійним спрямуванням» та «Міжкультурна комунікація у професійній співпраці» 3 метою повноцінної реалізації професійних обов’язків та функцій у процесі подальшої професійної діяльності студенти повинні володіти англійською мовою, у тому числі за професійним спрямуванням на рівні В2 (згідно Загальноєвропейських рекомендацій щодо рівнів володіння мовою [1]).

Програма вивчення запропонованої навчальної дисципліни «Міжкультурна комунікація у професійній співпраці» укладено також відповідно до освітньопрофесійної програми підготовки військових фахівців освітньо-кваліфікаційного рівня «бакалавр» у закладах вищої освіти України.

Предметом вивчення даної навчальної дисципліни є здобуття знань, формування, розвиток і вдосконалення мовленнєвих умінь та навичок, які забезпечують міжкультурну комунікацію у контексті професійної діяльності в усній та письмовій формах.

Метою вивчення навчальної дисципліни «Міжкультурна комунікація у професійній співпраці» є формування у курсантів міжкультурної компетентності як вагомої складової професійної компетентності майбутніх фахівців бойового оперативного забезпечення. Програма навчальної дисципліни визначає міжкультурну компетентність як ключову, яка формується у курсантів у процесі вивчення згаданої 
дисципліни у тісному взаємозв'язку 3 наступними компетентностями: 1) лінгвокультурною як якістю особистості, що характеризує її обізнаність у професійнокомунікативній сфері знань, відображає готовність та здатність до взаєморозуміння та взаємодії з представниками іншого лінгвокультурного соціуму на основі оволодіння знаннями про іншу лінгвокультуру і особистісного соціального досвіду під час розв'язання професійних завдань на міжнародному рівні; 2) соціокультурною як здатністю до взаємодії у ситуаціях повсякденного життя, підтримки, соціальних контактів, а також ситуаціях професійного характеру; здатністю до взаємодії з іншими та пізнання їх способу життя; 3) дискурсивною як здатністю будувати єдине смислове ціле iз серії висловлювань та сполучати висловлювання у структурований дискурс $[6 ; 8 ; 11$; $12 ; 13 ; 15 ; 16]$.

У результаті вивчення дисципліни у майбутніх фахівців бойового та оперативного забезпечення повинні бути сформовані наступні знання, навички i уміння, що $\epsilon$ компонентами міжкультурної компетентності: 1) лексичні знання (близько 500 вузькоспеціалізованих лексичних одиниць, у тому числі термінів); граматичні знання (граматичних конструкцій в межах відібраного навчального мінімуму, необхідного для ведення дискусії, бесіди, тощо); знання різних типів дискурсів та правил їх побудови; соціокультурні знання (про іншу лінгвокультуру, країнознавчі особливості, розуміння важливих і різнопланових міжнародних соціокультурних проблем), полікультурні знання; 2) мовленнєві навички і уміння (читання та розуміння текстів професійного характеру 3 метою як загального ознайомлення 3 інформацією, так і вилучення конкретної інформації; сприйняття на слух і розуміння мовлення професійного характеру іноземною мовою як при безпосередньому спілкуванні, так і в звукозаписі (що подається в нормальному темпі); усного та письмового перекладу іншомовних текстів професійної тематики, діалогічного та монологічного мовлення (складання діалогів, повідомлень професійного характеру (інформаційні (повідомлення, підтвердження, заперечення інформації); оцінні (похвала, схвалення); етикетні (привітання, прощання, вибачення); імперативні (наказ, розпорядження, заборона, порада), ведення дискусій, бесід, міжнародних військових переговорів 3 партнерами - представниками інших країн) та письма (написання повідомлення, наказу, службового подання, звіту, інструкції у 
письмовому вигляді іноземною мовою); створювати і розуміти професійно орієнтований дискурс з урахуванням особливостей комунікативної ситуації).

Висновки. Як доводять результати здійсненого аналізу, визначене коло знань, навичок і умінь, що формуються у курсантів у процесі вивчення навчальних дисциплін «Іноземна мова», «Іноземна мова за професійним спрямуванням» та «Міжкультурна комунікація у професійній співпраці» забезпечує формування і розвиток усіх визначених i представлених вище структурних компонентів міжкультурної компетентності майбутніх фахівців бойового та оперативного забезпечення.

Перспективи подальших досліджень полягають в експериментальній перевірці ефективності запропонованого спецкурсу «Міжкультурна комунікація у професійній співпраці» у процесі формування у майбутніх фахівців бойового та оперативного забезпечення міжкультурної компетентності.

\section{References}

1. Zagalnoevropeiski Rekomendatsii $z$ movnoi osvitu: vyvchenia, vykladania, otsiniuvania [Common European Framework of Reference for Languages : Learning, Teaching and Assessment]. Kyiv: Lenvit. 2003.

2. Kohut I. Informatsiina kompetentnist yak strukturnyi component profesiinopedagogichnoi komunikatyvnoi kompetentnosti pedagoga v suchasnomu osvitnomu prostori [Information competence as a structural component of professional and pedagogical communicative competence of educator in modern educational environment] Osvitologichnyi dyskurs. 2018. No. 3-4. P. 234-245.

3. Korneva Z.M. Metodika formuvannia mizhkuiturnoi profesiino orientovanoi komunikatyvnoi kompetentnosti studentiv vyshchogo tekhnichnogo navchalnogo zakladu [Teaching methods of building intercultural profesioanlly oriented communicative competence for students of technical school] Visnyk Chernigivskogo natsinalnogo ped. un-tu. Pedagogichni nauky. 2016. No. 141. P. 94-99.

4. Mykytenko N.O. Tekhnologia formuvannia inshomovnoi profesiinoi kompetentnosti maibutnikh fahivtsiv pryrodnychoho profiliu [Technology of forming foreign language professional competence in future specialists of natural profile] : monografiia. Ternopil: TNPU. 2011. $411 \mathrm{p}$.

5. Mykytenko N.O. Chynnyky formuvannia zmistu dystsypliny «Inozemna mova profesiinoho spriamuvannia» [Factors for forming the content of the discipline "Foreign language of professional orientation"]. Visnyk Lvivskoho Natsionalnoho universytetu imeni Ivana Franka. Seria pedahohichna. 2010. Vol. 26. P. 93-103.

6. Pet'ko L.V. Koncepcija sozdanija uchebnyh posobij dlja vstupitel'nogo jekzamena v magistraturu po inostrannomu jazyku professional'noj napravlennosti [Conception of creating of the textbooks for taking an entrance examination in foreign language in professional way to 
magistracy]. Innovacii v obrazovanii. Moskva: Sovremennaja gumanitarnaja akademija, 2014. No. 4. P. 63-74.

7. Pluzhnyk I.L. Formirovanie mezhkulturnoi kompetentsii studentov humanitarnogo profilia $v$ protsese profesionalnoi podgotovki [Building intercultural competence in the students of Humanities in professionally oriented training]. Doctor's thesis. Tuimen. 2003.

8. Popova O.V. (2016) Lingvokulturnyi aspect profesiinoi pidgotovky maibutnikh menedzheriv [Linguo-cultural aspect of professional training of prospective managers] Dukhovnist osobystosti: metodologiia, teoriia i practuka. 2016. No. 1(70). C. 120-126. [

9. Khorunzha L.L. Rozvytok etychnoi kompetentnosti maibutnogo vchytelia yak bagatofaktornyi protses [Development of prospective teacher's ethical competence as multifarious process ] Pedagogika i psykhologiia profesinoi osvity [Pedagogics and psychology of professional education]. 2003. No. 5.

10. Cherezova I.O. Komunikatyvna kompetentnist yak integralna yakist osobystosti [Communicative competence as an integral feature of personality] naukivyi visnyk Khersonskogo derzhavnogo universitetu. Psykhologichni nauky. 2014. 1(1). P. 103-107.

11. Brown H.D. (1987) Principles of Language Learning and Teaching. Eglewood Cliffs:Prentice Hall Regents, 1987. 467 p.

12. Byram M., Zarate G. Investigating Cultural Studies in Foreign Language Teaching. Clevedon, Philadelphia, cop.1991. 219 p.

13. Canale M., Swain M. (1980) Theoretical bases of communicative approaches to second language. 1980.

14. Chen G.M. Foundation of intercultural communication. Boston. 1998. 340 p.

15. Van Ek J. A., Trim J. L. M. Vantage.Cambridge University Press. 2001. 187 p.

16. Pet'ko L. Multicultural upbringing of students and the formation of professionally oriented foreign language teaching environment. Perspectives of research and development : Collection of scientific articles. - SAUL Publishing Ltd, Dublin, Ireland, 2017. Pp. 164-170.

17. Pet'ko L. Preparing higher school graduates in foreshortening of leader competencies for 2020. Topical questions of contemporary science: Collection of scientific articles. Aspekt Publishing of Budget Printing Center, Taunton, MA 02780, United States of America, 2017. Ph. 467-472.

\section{Translation of the Title, Abstract and References to the Author's Languag}

\section{УДК 317-057.86 (477)}

Любас Анжеліка. Зміст формування міжкультурної компететності майбутніх фахівців бойового та оперативного забезпечення.

Стаття присвячена актуальній проблемі оволодіння майбутніми фахівцями бойового та оперативного забезпечення міжкультурною компетентністю. 3 урахуванням результатів сучасних досліджень міжкультурну компетентність майбутніх фахівців бойового та оперативного забезпечення трактуємо як здатність цих фахівців взаємодіяти з професіоналами - представниками інших культур на основі врахування їхніх цінностей, 
норм, традицій, уявлень, а також обирати комунікативно доцільні способи невербальної i вербальної поведінки 3 метою вирішення завдань професійного характеру. До компонентів міжкультурної компетентності майбутніх фахівців бойового оперативного забезпечення відносимо знання (мовні, мовленнєві, полікультурні, вербальних та невербальних комунікативних правил поведінки, когнітивні), вміння та навички (мовленнєві навички та вміння, когнітивні навички, здатність контролювати власні дії під час спілкування). У процесі вивчення навчальних дисциплін «Іноземна мова», «Іноземна мова за професійним спрямуванням» студенти оволодівають основними елементами системи іноземної мови, розвивають та вдосконалюють мовленнєві знання, уміння та навички, які забезпечують спілкування іноземною мовою у професійній сфері. Введення до навчальних планів підготовки бакалаврів третього року навчання дисципліни «Міжкультурна комунікація у професійній співпраці» та організація навчальних й виробничих польових практик англійською мовою передбачає реалізацію міжкультурної комунікації у процесі виконання професійних обов'язків і функцій.

Ключові слова: міжкультурна компетентність, майбутні фахівці бойового оперативного забезпечення, навчальна дисципліна, навчальні плани.

\section{Лimepamypa}

1. Загальноєвропейські Рекомендації з мовної освіти: вивчення, викладання, оцінювання / наук. ред. укр. вид. С. Ніколаєва. Київ : Ленвіт, 2003. 273 с.

2. Когут I. Інформаційна компетентність як структурний компонент професійнопедагогічної комунікативної компетентності педагога в сучасному освітньому просторі. Освітологічний дискурс. 2018. № 3-4. С. 234-245.

3. Корнєва 3. М. Методика формування міжкультурної професійно орієнтованої комунікативної компетентності студентів вищого технічного навчального закладу. Вісник Чернігівського наџіонального педагогічного університету. Серія : Педагогічні науки. 2016. Вип. 141. С. 94-99.

4. Микитенко Н.О. Технологія формування іншомовної професійної компетентності майбутніх фахівців природничого профілю : монографія. Тернопіль : ТНПУ, 2011. $411 \mathrm{c.}$

5. Микитенко Н.О. Чинники формування змісту дисципліни «Іноземна мова професійного спрямування». Вісник Львів. нац. ун-ту. ім. I. Франка. Серія педагогічна. 2010. Вип. 26. С. 93-103.

6. Петько Л.В. Концепция создания учебных пособий для вступительного экзамена в магистратуру по иностранному языку профессиональной направленности. Инновации в образовании : научно-метод. журнал / учред. Современная гуманитарная академия ; гл. ред. И.В.Сыромятников. Москва: Современная гуманитарная академия, 2014. № 4. С. 63-74.

7. Плужник И.Л. Формирование межкультурной коммуникативной компетенции студентов гуманитарного профиля в процессе профессиональной подготовки: дис... д-ра пед. наук: 13.00.01. Тюмень, 2003. 335 с.

8. Попова О.В. Лінгвокультурний аспект професійної підготовки майбутніх менеджерів. Духовність особистості: методологія, теорія і практика. Сєвєродонецьк, 2016. Вип. 1 (70). С.120-126. 
9. Хоружа Л.Л. Розвиток етичної компетентності майбутнього вчителя як багатофакторний процес. Педагогіка і психологія професійної освіти. 2003. № 5. С. $42-44$.

10. Черезова I. О. Комунікативна компетентність як інтегральна якість особистості. Науковий вісник Херсонського державного університету. Серія: Психологічні науки. 2014. Вип. 1(1). С. 103-107.

11. Brown H. D. Principles of Language Learning and Teaching. Eglewood Cliffs:Prentice Hall Regents, 1987. 467 p.

12. Byram M., Zarate G. Investigating Cultural Studies in Foreign Language Teaching. Clevedon, Philadelphia, cop., 1991. 219 p.

13. Canale M., Swain M.. Theoretical bases of communicative approaches to second language teaching and testing. Applied Linguistics, 1980. P.1-47.

14. Chen G. M. Foundation of intercultural communication. Boston, 1998. 340 p.

15. Van Ek J. A., Trim J. L. M. Vantage.Cambridge University Press, 2001. 187 p.

16. Pet'ko L. Multicultural upbringing of students and the formation of professionally oriented foreign language teaching environment. Perspectives of research and development : Collection of scientific articles. - SAUL Publishing Ltd, Dublin, Ireland, 2017. Pp. 164-170.

17. Pet'ko L. Preparing higher school graduates in foreshortening of leader competencies for 2020. Topical questions of contemporary science: Collection of scientific articles. Aspekt Publishing of Budget Printing Center, Taunton, MA 02780, United States of America, 2017. Ph. 467-472. 